\title{
MEKANISME PARASITISME TRICHODERMA HARZIANUM TERHADAP FUSARIUM OXYSPORUM PADA SEMAI ACACIA MANGIUM
}

\author{
Susanti Tasik ${ }^{1}$, Siti Muslimah Widyastuti ${ }^{2}$, \& Harjono $^{2}$ \\ ${ }^{1}$ Fakultas Kehutanan, Universitas Negeri Papua \\ Jl. Gunung Salju, Amban Manokwari, Papua Barat, \\ ${ }^{2}$ Fakultas Kehutanan, Universitas Gadjah Mada \\ Jl. Agro No. 1, Bulaksumur, Daerah Istimewa Yogyakarta 55281 \\ E-mail : iselmom@yahoo.com
}

\begin{abstract}
Mechanism of parasitism of Trichoderma harzianum on Fusarium oxysporum on Acacia mangium seedlings. Fusarium oxysporum is one of the most important soil-borne fungi the causal agent of damping-off disease. Detailed information it needed to know how the pathogen can be inhibited by Trichoderma harzianum. The objective of this research was to investigate the inhibition mechanism of T. harzianum on F. oxysporum in vitro and in planta. Green Flourescent Protein (GFP) T. harzianum was used as biocontrol agent of $F$. oxysporum. An in vitro inhibition test of $T$. harzianum was performed using dual culture method. In the in planta inhibition tests, seedlings of A. mangium were applied with GFP T. harzianum two days before inoculation of F. oxysporum; GFP T. harzianum was simultaneously applied with $F$. oxysporum and GFP T. harzianum was applied two days after inoculation of $F$. oxysporum. The inhibition effect of $T$. harzianum GFP was observed at seven days incubation, indicated by attachment of $T$. harzianum to $F$. oxysporum hyphae. GFP $T$. harzianum hyphae covered the colonies of $F$. oxysporum at 12 days after incubation. The highest life percentage of A. mangium seedlings was found on the treatment of GFP T. harzianum two days before inoculation of $F$. oxysporum $(82.22 \%)$, whereas the lowest life percentage was found on seedling applied with GFP T. harzianum two days after inoculation of F. oxysporum (64.44\%).
\end{abstract}

Key words: Acacia mangium, damping-off, Fusarium oxysporum, green fluorescent protein (GFP), Trichoderma harzianum

\section{ABSTRAK}

Mekanisme parasitisme Trichoderma harzianum terhadap Fusarium oxysporum pada semai Acacia mangium. Fusarium oxysporum adalah salah satu jamur patogen tular tanah yang penting dan dapat menyebabkan penyakit rebah kecambah. Informasi terperinci mengenai jamur tersebut diperlukan untuk mengetahui bagaimana pertumbuhan jamur tersebut dapat dihambat oleh Trichoderma harzianum. Tujuan dari penelitian ini adalah untuk mengetahui mekanisme penghambatan $T$. harzianum terhadap F. oxysporum secara in vitro and in planta. Trichoderma harzianum green fluorescent protein (GFP) digunakan sebagai agen pengendali hayati terhadap $F$. oxysporum. Pengujian secara in vitro menggunakan metode kultur ganda. Susunan perlakuan pada pengujian secara in planta yaitu, aplikasi $T$. harzianum GFP dua hari sebelum inokulasi $F$. oxysporum; aplikasi $T$. harzianum GFP 2 bersamaan dengan inokulasi $F$. oxysporum; aplikasi $T$. harzianum GFP dua hari setelah inokulasi F. oxysporum. Pengaruh penghambatan T. harzianum GFP diamati pada tujuh hari setelah inkubasi, indikasinya ialah adanya penempelan hifa $T$. harzianum GFP pada hifa $F$. oxysporum. Hifa T. harzianum GFP menutupi koloni $F$. oxysporum pada 12 hari setelah inkubasi. Rata-rata persentase hidup semai $A$. mangium tertinggi ditunjukkan pada perlakuan aplikasi $T$. harzianum GFP dua hari sebelum inokulasi $F$. oxysporum yaitu sebesar 82,22 \%, dan terendah pada perlakuan aplikasi $T$. harzianum GFP dua hari setelah inokulasi F. oxysporum sebesar $64,44 \%$.

Kata kunci: Acacia mangium, Fusarium oxysporum, green fluorescent protein (GFP), rebah kecambah, Trichoderma harzianum

\section{PENDAHULUAN}

Pembangunan Hutan Tanaman Industri (HTI) merupakan salah satu model pengelolaan hutan yang dapat menjamin ketersediaan bahan baku kayu, terutama untuk kebutuhan industri secara kontinyu. Sejak dicanangkan tahun 1984, pembangunan HTI terus mengalami peningkatan. Salah satu faktor yang perlu diperhatikan dalam peningkatan produktivitas HTI adalah penggunaan bibit yang unggul dari jenis yang unggul pula. Sebagai salah satu spesies pohon yang penting pada HTI (Hardiyanto \& Arisman, 2004), Mangium (Acacia mangium Willd.) juga memiliki beberapa keunggulan. Keunggulan yang dimaksud adalah pertumbuhannya yang cepat (fast growing species) serta kayunya memiliki sifat yang sesuai untuk bahan baku pulp dan kertas, kayu pertukangan, konstruksi ringan dan arang. Untuk menunjang ketersediaan bahan baku, diperlukan 
bibit A. mangium yang sehat dan jumlah yang cukup guna pencapaian target produksi maksimal yang diharapkan.

Ketersediaan bibit $A$. mangium yang sehat, diawali dengan ketersediaan semai yang sehat terutama dari serangan penyakit di persemaian. Semai $A$. mangium di persemaian sangat rentan terutama terhadap patogen tular tanah (soil born pathogen). Salah satu patogen tular tanah yang sering menyerang semai di areal persemaian adalah Fusarium oxysporum. Beberapa semai di persemaian yang dilaporkan terserang patogen ini, diantaranya semai Pinus merkusii (Achmad et al., 1997), P. Pinea (Machón et al., 2009) dan Eucalyptus viminalis (Salerno et al., 2000).

Pengendalian terhadap patogen tular tanah dapat dilakukan secara kimia dan hayati. Pengendalian secara kimia menimbulkan dampak negatif lebih banyak dibandingkan dampak positif. Meningkatnya bahaya polusi kimia pada lingkungan, residu pestisida pada makanan dan meningkatnya patogen yang tahan terhadap fungisida merupakan beberapa dampak yang ditimbulkan (Widyastuti, 2007). Pengendalian secara hayati memiliki dampak negatif yang hampir tidak ada, karena merupakan metode pengendalian yang mencakup penggunaan patogen dengan jenis virulensi yang rendah, budidaya tanaman inang yang lebih tahan dan penggunaan mikroorganisme antagonis yang menghambat kelangsungan hidup atau aktivitas patogen dalam menyebabkan penyakit (Widyastuti, 2007). Sebagai salah satu agen pengendali hayati (Bio kontrol), Trichoderma spp. merupakan mikroorganisme yang memiliki beberapa keunggulan, salah satunya adalah sebagai mikoparasit yang agresif, dimana Trichoderma spp. mampu menyerang patogen yang sebelumnya telah berada di suatu habitat tertentu.

Trichoderma spp. merupakan salah satu agen pengendali hayati yang paling potensial untuk dikembangkan sebagai pengendali hayati jamur tanah (Nakas \& Hagedorn, 1990). Penelitian yang dilakukan oleh Widyastuti et al. (2003) dan Widyastuti \& Hariani (2006) mengindikasikan bahwa Trichoderma efektif untuk menghambat patogen tular tanah seperti Sclerotium rolfsii, Fusarium sp., Rhizoctonia solani dan $F$. oxysporum dengan berbagai mekanisme yaitu kompetisi, antibiosis dan mikoparasit. Tujuan dari penelitian ini adalah untuk mengetahui mekanisme penghambatan terhadap $F$. oxysporum penyebab penyakit rebah semai pada semai $A$. mangium menggunakan $T$. harzianum.

\section{METODE PENELITIAN}

Tempat dan Waktu. Penelitian dilaksanakan di Laboratorium Perlindungan dan Kesehatan Hutan dan Laboratorium Struktur dan Sifat Kayu, Fakultas Kehutanan, Universitas Gadjah Mada serta Laboratorium Penelitian dan Pengujian Terpadu (LPPT) Unit III, Universitas Gadjah Mada pada bulan Januari hingga Maret 2010.

Isolasi Fusarium oxysporum, Trichoderma harzianum GFP dan Semai Acacia mangium. Isolat F. oxysporum merupakan koleksi Laboratorium Perlindungan dan Kesehatan Hutan Universitas Gadjah Mada yang diisolasi dari semai $A$. mangium sakit umur 2 minggu yang menunjukkan gejala rebah semai. Isolat T. harzianum GFP merupakan koleksi Dr. Agus Purwantara peneliti pada Balai Bioteknologi Perkebunan Indonesia-Bogor). Semai A. mangium diperoleh dengan menumbuhkan bibit $A$. mangium pada media tanah steril.

Pengendalian Fusarium oxysporum dengan Tricoderma harzianum In Vitro. Daya antagonistik $T$. harzianum terhadap $F$. oxysporum diuji menggunakan metode dual culture yang dimodifikasi dari Goltapeh \& Danesh (2006). Fusarium oxysporum ditumbuhkan 2 hari lebih awal dari T. harzianum GFP pada suhu ruangan $25{ }^{\circ} \mathrm{C}$. Hal ini dikarenakan pertumbuhan koloni $T$. harzianum GFP lebih cepat dibandingkan koloni $F$. oxysporum. Jarak antara koloni $F$. oxysporum dan $T$. harzianum GFP adalah $3 \mathrm{~cm}$, dengan jarak dari masing-masing tepi cawan Petri adalah $3 \mathrm{~cm}$. Untuk pengamatan mikroskopis, diberi gelas benda di antara koloni $F$. oxysporum dan $T$. harzianum GFP. Pengamatan secara makroskopis dilakukan sebelum dan setelah terjadi kontak antar hifa serta setelah koloni $T$. harzianum GFP terlihat telah menutupi seluruh koloni $F$. oxysporum. Sedangkan pengamatan secara mikroskopis dilakukan setelah terjadi kontak antar hifa. Pengukuran terhadap daya hambat secara in vitro dari $T$. harzianum dilakukan dengan mengukur diameter koloni $F$. oxysporum (kontrol) yang ditumbuhkan pada media PDA tanpa $T$. harzianum GFP dan diameter koloni $F$. oxysporum yang ditumbuhkan dengan T. harzianum GFP pada waktu yang sama. Pengukuran dilakukan hingga masa inkubasi 10 hari. 
Perhitungan persentase penghambatan berdasarkan rumus :

$$
C=\frac{\mathrm{a}-\mathrm{b}}{\mathrm{a}} \times 100 \%
$$

dengan :

$\mathrm{C}=$ daya hambat

$\mathrm{a}=$ rerata luas kontrol (koloni $F$. oxysporum)

$\mathrm{b}=$ rerata luas koloni $F$. oxysporum dengan $T$. harzianum GFP

In Planta. Aplikasi in planta dilakukan dengan menggunakan 4 unit perlakuan, yaitu semai A. mangium sehat (kontrol), aplikasi $T$. harzianum GFP dua hari sebelum inokulasi $F$. oxysporum; aplikasi $T$. harzianum GFP 2 bersamaan dengan inokulasi $F$. oxysporum; aplikasi $T$. harzianum GFP dua hari setelah inokulasi $F$. oxysporum. Ulangan yang dilakukan adalah sebanyak 3 ulangan/ 3 pot dengan jumlah semai $A$. mangium untuk tiap ulangan sebanyak 15 semai. Total benih semai $A$. mangium yang dibutuhkan untuk aplikasi in planta tiap ulangan sebanyak 45 semai. Selanjutnya semai $A$. mangium sehat diinokulasi dengan suspensi spora $F$. oxysporum dan T. harzianum GFP sesuai dengan kombinasi telah ditetapkan. Umur semai saat diinokulasi adalah 7 hari dan pengamatan dilakukan setelah 2, 6, dan 12 hari setelah inokulasi. Pengamatan yang dilakukan meliputi gejala dan tanda serta persentase jumlah semai yang hidup pada akhir pengamatan untuk masing-masing perlakuan.

\section{HASIL DAN PEMBAHASAN}

Penghambatan Trichoderma harzianum GFP terhadap Fusarium oxysporum. Trichoderma harzianum GFP digunakan sebagai agen pengendali hayati terhadap $F$. oxysporum sebagai jamur patogen pada semai A. mangium. Hasil pengamatan secara makroskopis menunjukkan bahwa biakan murni T. harzianum GFP (Gambar 1) berwarna hijau dan putih kekuning-kuningan, sedangkan secara mikroskopis hifa T. harzianum GFP terlihat berbeda ketika dilihat dibawah mikroskop fluoresen dan mikroskop cahaya (Gambar 2).

Aplikasi in Vitro. Miselium F. oxysporum dan T. harzianum GFP mulai bersinggungan dan terjadi kontak pada hari ke-4 setelah T. harzanium GFP ditanam. Trichoderma harzianum GFP mulai tumbuh dan menutupi koloni $F$. oxysporum pada hari ke-10 setelah terjadi kontak (Gambar 3). Persentase daya hambat mulai meningkat hingga mencapai $79,55 \%$ (masa inkubasi 12 hari) yang dimulai dari 6,99\% (masa inkubasi
5 hari) (Gambar 4). Hal tersebut mengindikasikan adanya kemampuan $T$. harzianum GFP sebagai agen pengendali hayati yang mempunyai kemampuan mikoparasit, yaitu kemampuan dalam hal memproduksi enzim-enzim ekstraseluler yang dapat merusak dinding sel jamur lain dan kemudian digunakan sebagai sumber makanan (Harjono \& Widyastuti, 2001).

Daya antagonistik T. harzianum GFP terhadap F. oxysporum dengan metode dual culture pada 7 hari masa inkubasi menunjukkan bahwa terjadi proses penempelan hifa $T$. harzianum GFP terhadap hifa F. oxysporum pada daerah kontak (Gambar 5A) dan tidak terjadi pelilitan. Penempelan merupakan tahapan ketiga dari pola interaksi mikoparasitisme yang dimiliki oleh Trichoderma spp. Tahapan pertama dari pola interaksi mikoparasitisme antara Trichoderma spp. dengan jamur patogen adalah pertumbuhan kemotropik, dimana pada tahap ini terjadi proses rangsangan kimiawi dari inang terhadap fungi antagonis. Tahap kedua adalah pengenalan atau rekognisi, pada tahap ini pada beberapa kasus bersifat spesifik sehingga sifat antagonistik Trichoderma spp. hanya efektif untuk fungi patogen tertentu. Tahap keempat adalah penguraian dinding sel inang, terkait dengan enzim-enzim yang dihasilkan. Kemampuan Trichoderma spp. dalam menghasilkan enzim pengurai dinding sel (kitinolitik, selulolitik dan glukanolitik) telah diteliti dan diuji kemampuannya (Kucuk \& Kivan, 2003; Widyastuti et al., 2001; Witkowska \& Maj, 2002). Selanjutnya seiring dengan bertambahnya masa inkubasi (Gambar 5C) interaksi antara T. harzianum GFP dengan $F$. oxysporum ditunjukkan melalui kemampuan mikoparasitisme yaitu T. harzianum GFP mampu tumbuh dan menutupi sebagian besar koloni $F$. oxysporum. Kemampuan mikoparasitisme adalah kemampuan mikroba memproduksi enzim ekstraseluler untuk merusak dinding sel fungi lain yang kemudian digunakan sebagai sumber makanan (Harjono \& Widyastuti, 2001).

Aplikasi in Planta. Aplikasi in planta dilakukan untuk mengetahui efektivitas $T$. harzianum GFP terhadap F. oxysporum di lapangan, karena kedua jamur tersebut hidup pada rhizosfer. Inokulasi semai $A$. mangium dengan $T$. harzianum GFP terlebih dahulu yaitu 2 hari sebelum inokulasi $F$. oxysporum, terlihat bahwa semai dalam kondisi sehat yaitu saat semai berumur 9 hari (Gambar 6A). Miselium F. oxysporum mulai terlihat pada hari ke-6 setelah inokulasi yaitu pada saat umur semai A. mangium 13 hari (Gambar 6B). Pada akhir pengamatan yaitu pada hari ke-12 setelah inokulasi, yaitu saat semai berumur 19 hari terdapat semai A. mangium yang mati (Gambar 6C). 


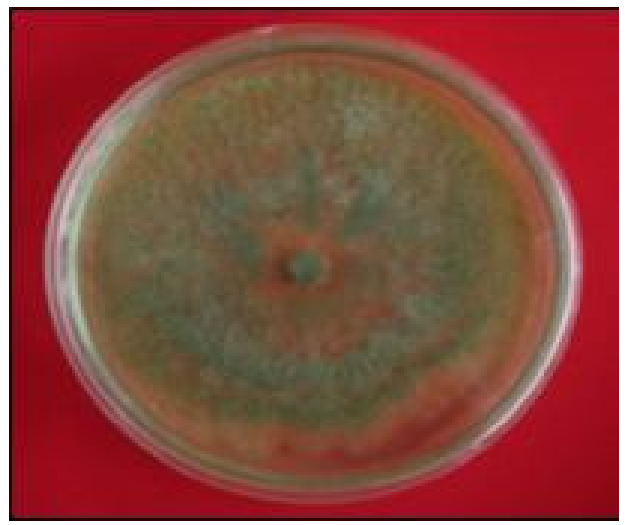

Gambar 1. Trichoderma harzianum GFP
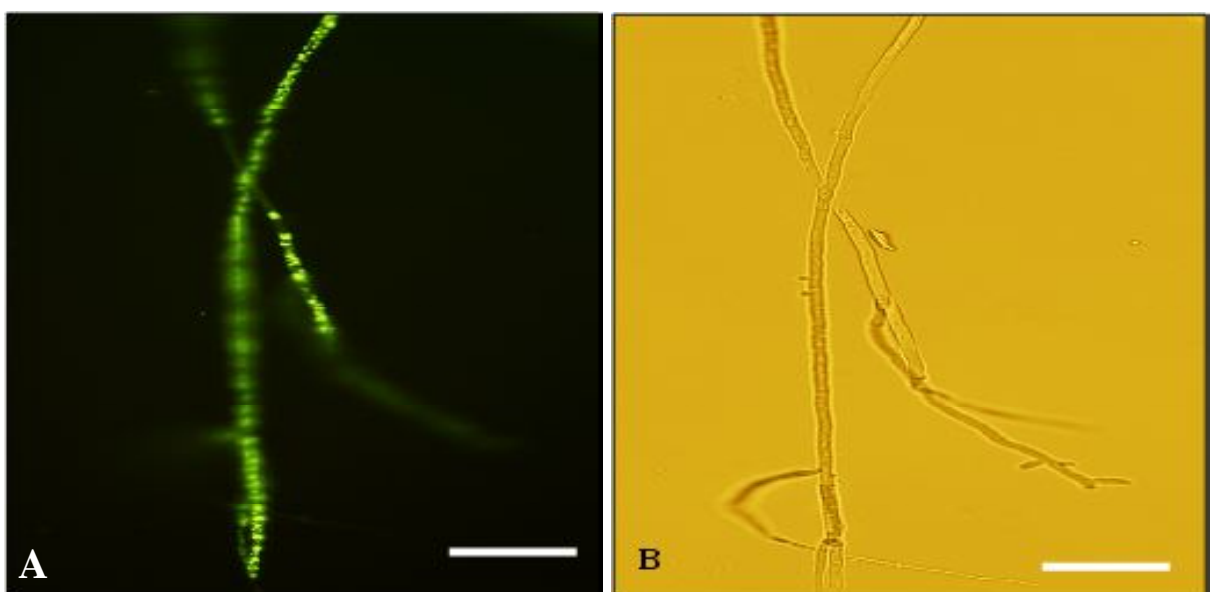

Gambar 2. Hifa Trichoderma harzianum GFP. (A) Hifa T. harzianum GFP (mikroskop fluoresen), (B) Hifa $T$. harzianum GFP (mikroskop cahaya). (Bar $=200 \mu \mathrm{m})$
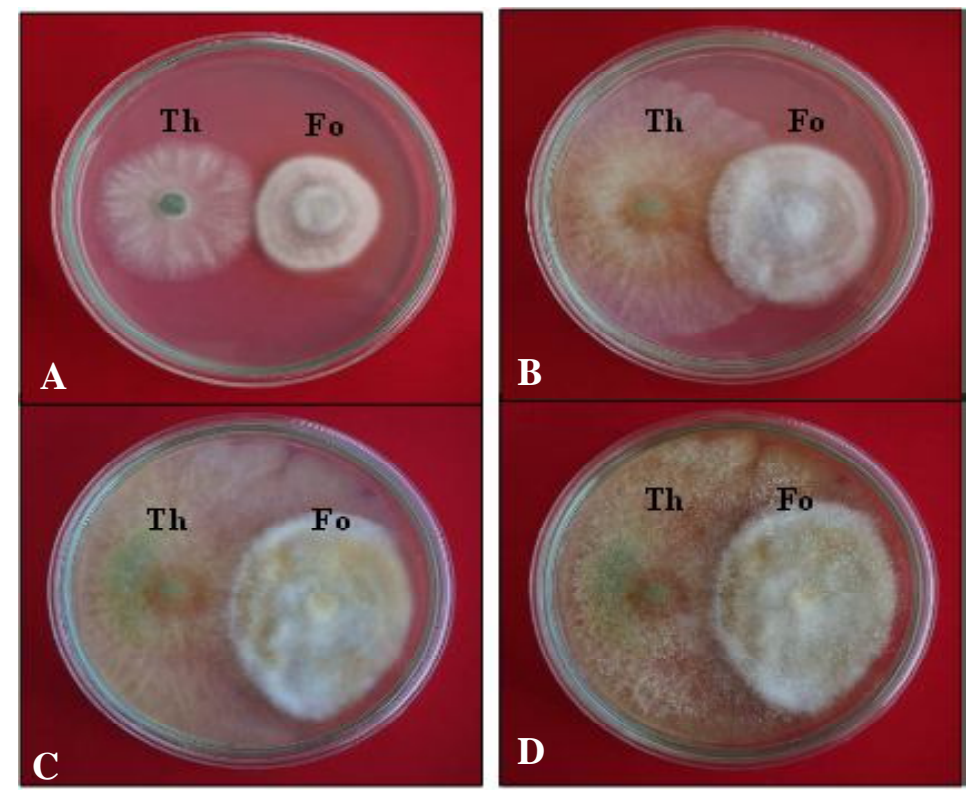

Gambar 3. Daya antagonistik Trichoderma harzianum GFP terhadap Fusarium oxysporum secara makroskopis. (Th) T. harzianum GFP; (Fo) F. oxysporum; 4 hari inkubasi (A); 7 hari inkubasi (B); 10 hari inkubasi (C); 12 hari inkubasi (D) 


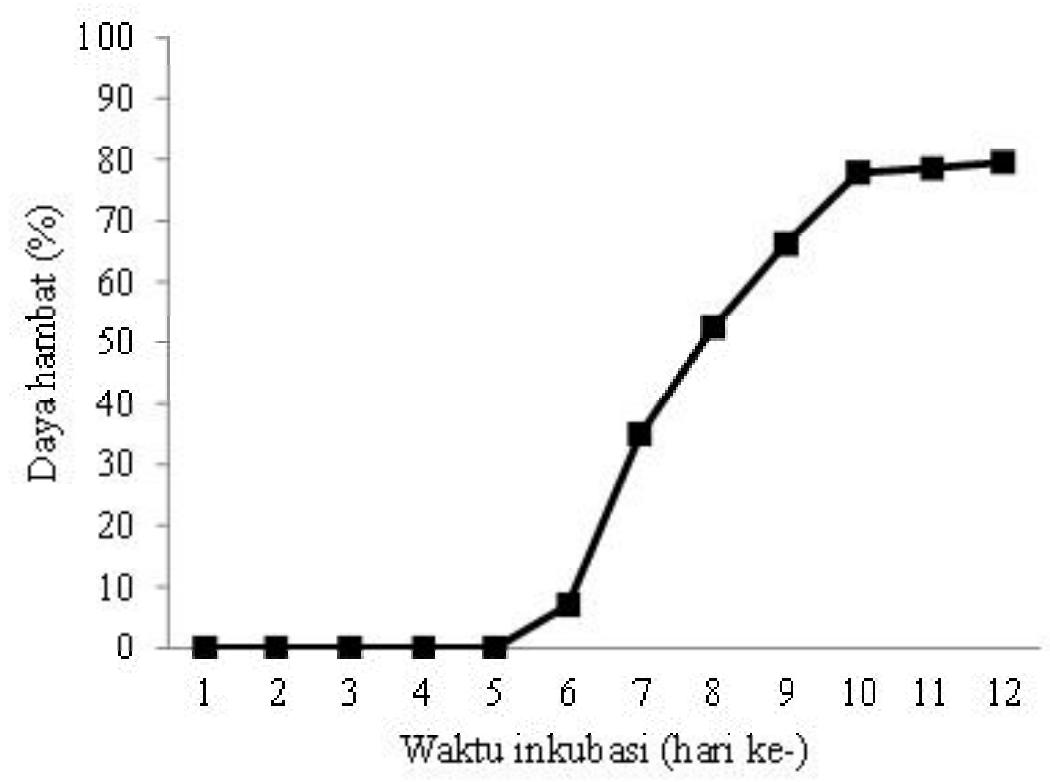

Gambar 4. Daya hambat Trichoderma harzianum GFP terhadap Fusarium oxysporum
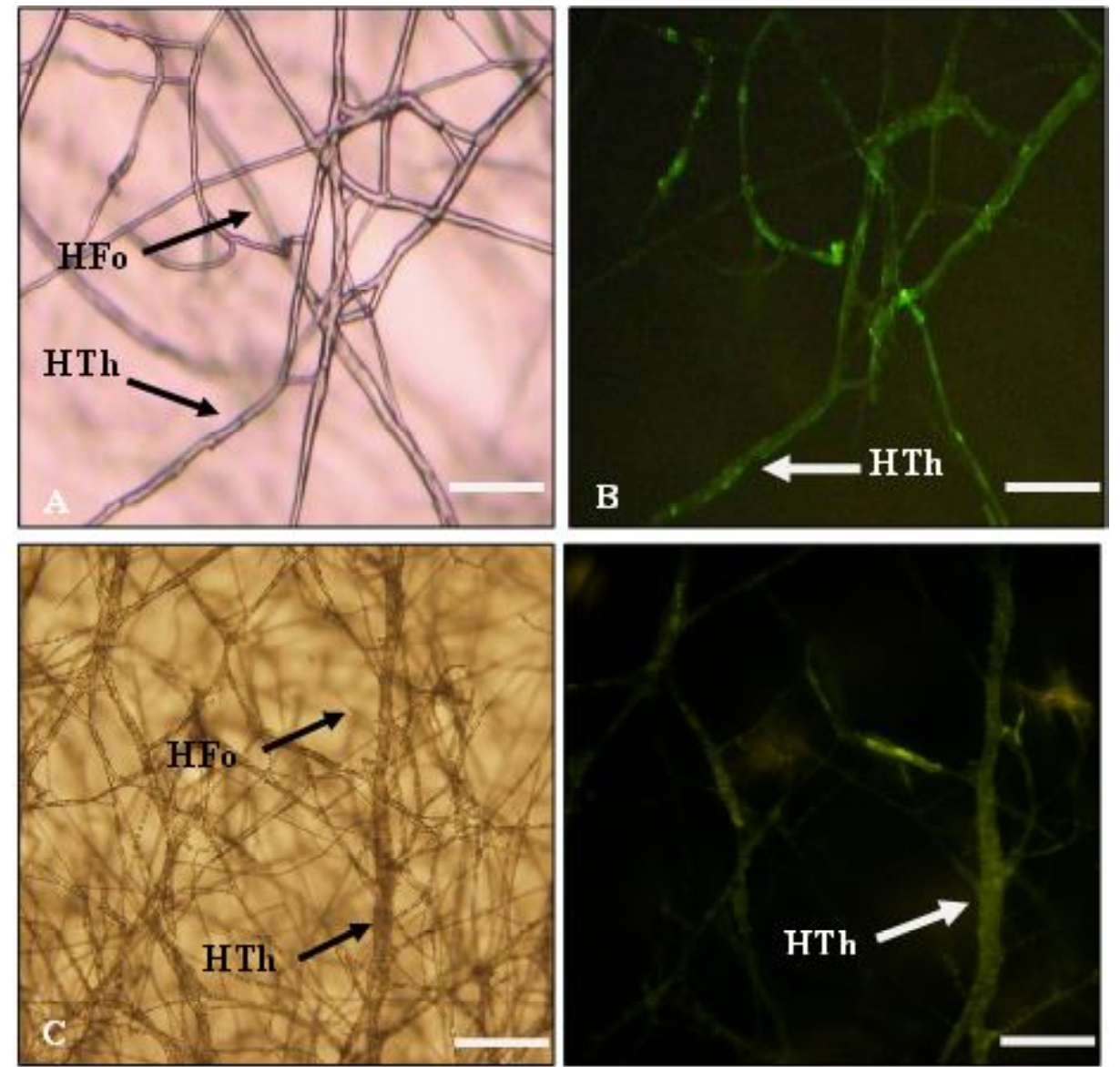

Gambar 5. Daya Parasitisme Trichoderma harzianum GFP terhadap Fusarium oxysporum secara mikroskopis. (A) Hasil foto dengan mikroskop cahaya umur 7 hari inkubasi; (B) Hasil foto dengan mikroskop fluoresen umur 7 hari inkubasi; (C) Hasil foto dengan mikroskop cahaya umur 12 hari inkubasi; (D) Hasil foto dengan mikroskop fluoresen umur 12 hari inkubasi; (HFo) Hifa F. oxysporum, (HTh) Hifa T. harzianum GFP. $($ Bar $=200 \mu \mathrm{m})$ 


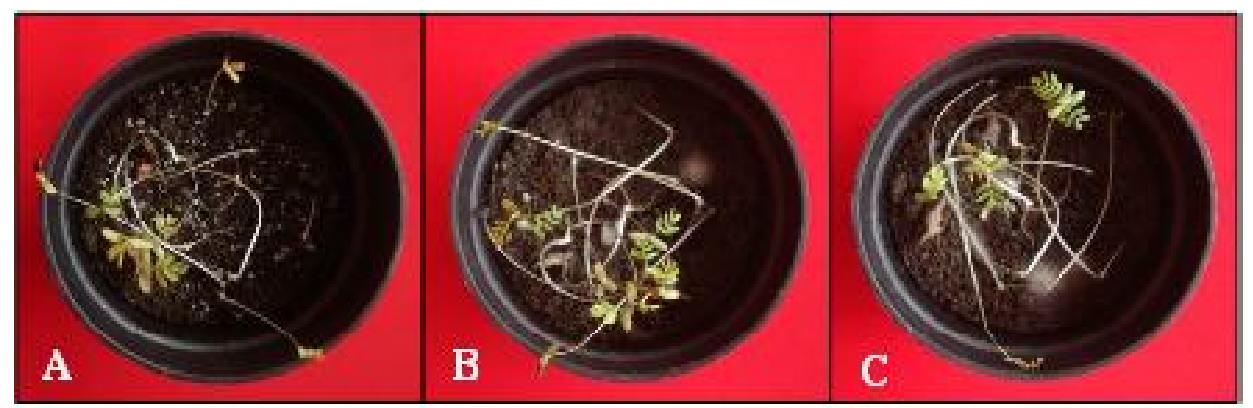

Gambar 6. Pengaruh Trichoderma harzianum GFP 2 hari sebelum inokulasi Fusarium oxysporum terhadap semai Acacia mangium. Umur semai (A) 9 hari, (B) 13 hari, (C) 19 hari

Perlakuan semai A. mangium yang diinokulasi F. oxysporum dan $T$. harzianum GFP secara bersamaan menunjukkan bahwa pada hari ke-2 setelah diinokulasi, yaitu saat semai $A$. mangium berumur 9 hari masih terlihat berada dalam kondisi sehat dan belum terlihat adanya miselium $F$. oxysporum berwarna putih yang menutupi semai A. mangium (Gambar 7A). Pada hari ke-6 setelah diinokulasi yaitu pada saat semai A. mangium berumur 13 hari sudah mulai terlihat adanya tanda yang ditunjukkan, yaitu dengan munculnya miselium $F$. oxysporum yang berwarna putih (Gambar 7B). Pada hari ke-13 (Gambar 7C) setelah inokulasi atau pada akhir pengamatan yaitu saat berumur 19 hari sebagian besar semai telah mati.

Inokulasi semai $A$. mangium dengan F. oxysporum 2 hari sebelum apliaksi T. harzianum GFP, menunjukkan bahwa pada hari ke-2 setelah inokulasi saat semai berumur 9 hari masih terlihat sehat (Gambar 8A), namun pada hari ke-6 setelah inokulasi miselium $F$. oxysporum terlihat menutupi semai A. mangium (Gambar 8B), begitu juga pada akhir pengamatan yaitu 12 hari setelah inokulasi saat semai berumur 19 hari, miselium $F$. oxysporum terlihat menutupi permukaan tanah dan sebagian besar telah menutupi semai $A$. mangium sehingga lebih banyak semai yang mati (Gambar $8 \mathrm{C}$ ).

Berdasarkan tiga unit perlakuan yang diaplikasikan pada semai $A$. mangium, terbukti bahwa apliaksi T. harzianum GFP 2 hari sebelum inokulasi F. oxysporum lebih efektif dibandingkan aplikasi T. harzianum GFP dan $F$. oxysporum bersamaan dan inokulasi $F$. oxysporum 2 hari sebelum inokulasi T. harzianum GFP. Hal ini ditunjukkan dengan keberadaan miselium $F$. oxysporum yang cenderung lebih sedikit (Gambar 6) seiring bertambahnya umur semai dibandingkan dua unit perlakuan lainnya (Gambar 7 dan 8). Grondona et al. (1997) menyatakan bahwa pemanfaatan $T$. harzianum telah terbukti menghambat beberapa jamur tular-tanah diantaranya patogen $F$. oxysporum. Inokulasi $T$. harzianum GFP dan F. oxysporum secara bersamaan juga menunjukkan hasil yang lebih baik dibandingkan inokulasi F. oxysporum 2 hari sebelum inokulasi T. harzianum GFP. Jamur di dalam tanah hidup bersama-sama dengan mikroba antagonis yang menyebabkan lingkungan menjadi miskin zat makanan dan terdapatnya metabolit yang beracun, yang berakibat pada ketidakmampuan spora jamur dalam berkecambah dan bereproduksi (Agrios, 2005). Pernyataan tersebut mengindikasikan adanya pengaruh dari keberadaan T. harzianum GFP yang walaupun diaplikasikan bersamaan dengan $F$. oxysporum, namun dapat menunjukkan daya antagonisnya yang ditandai dengan berkurangnya miselium $F$. oxysporum pada akhir pengamatan bila dibandingkan dengan perlakuan inokulasi $F$. oxysporum 2 hari sebelum aplikasi T. harzianum GFP. Inokulasi $F$. oxysporum 2 hari sebelum aplikasi $T$. harzianum GFP menunjukkan hasil yang paling tidak efektif. Hal ini dikarenakan $F$. oxysporum terlebih dahulu berada di semai dan tanah sehingga kemampuan $T$. harzianum GFP sebagai agen pengendali hayati tidak terlalu berpengaruh nyata, terlihat dengan banyaknya miselium F. oxysporum pada akhir pengamatan, baik pada semai maupun permukaan tanah dibanding dua unit perlakuan lainnya (Gambar 8).

Persentase hidup semai A. mangium setelah diinokulasi dengan tiga unit perlakuan yang berbeda menunjukkan pola yang berbeda (Gambar 9). Semai A. mangium yang diapliaksikan dengan T. harzianum GFP 2 hari sebelum inokulasi $F$. oxysporum menghasilkan rata-rata persentase hidup semai yang lebih tinggi $(82,22 \%)$, dilanjutkan dengan semai A. mangium yang diaplikasikan dengan $T$. harzianum GFP dan $F$. oxysporum secara bersamaan $(71,11 \%)$ dan semai $A$. mangium yang diinokulasi dengan F. oxysporum 2 hari sebelum aplikasi $T$. harzianum 


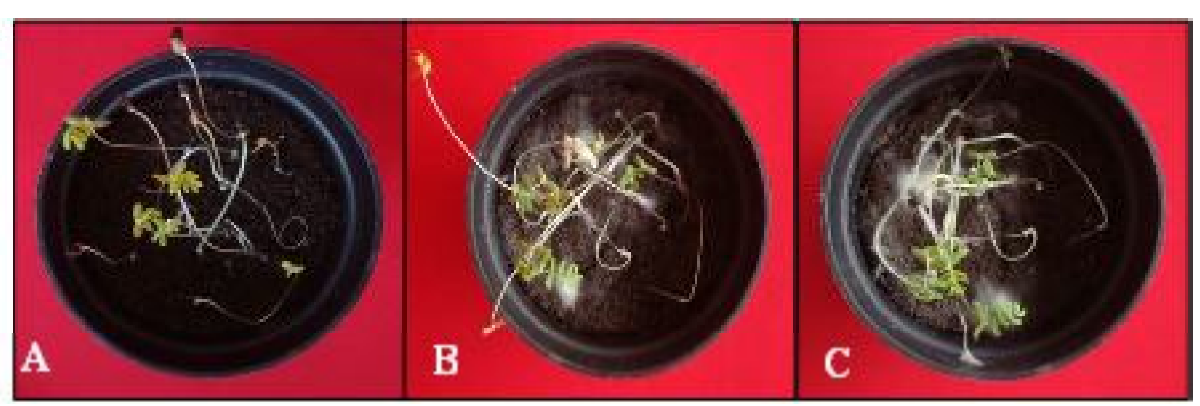

Gambar 7. Pengaruh inokulasi Trichoderma harzianum GFP dan Fusarium oxysporum secara bersamaan terhadap semai A. mangium. Umur semai (A) 9 hari, (B) 13 hari, (C) 19 hari setelah berkecambah.

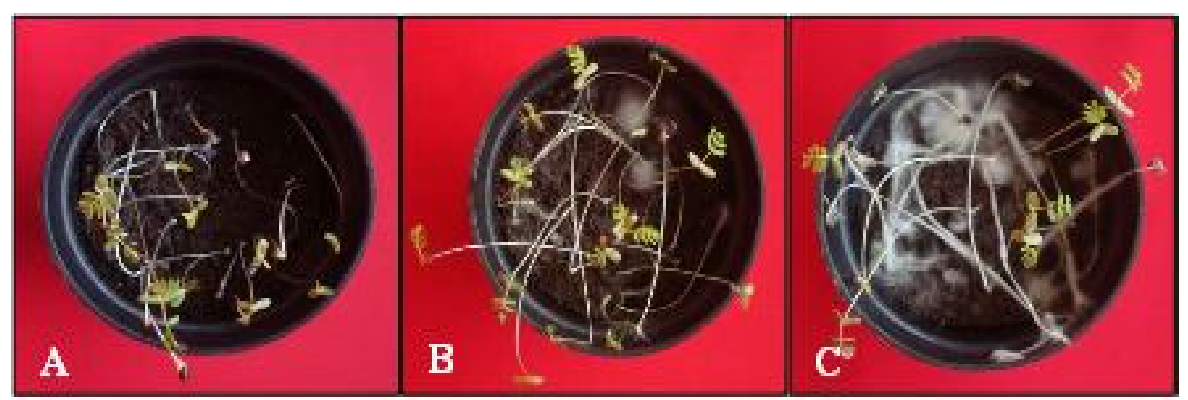

Gambar 8. Pengaruh inokulasi Fusarium oxysporum 2 hari sebelum inokulasi Trichoderma harzianum GFP terhadap semai Acacia mangium. Umur semai 9 hari (A), 13 hari (B), 19 hari (C)

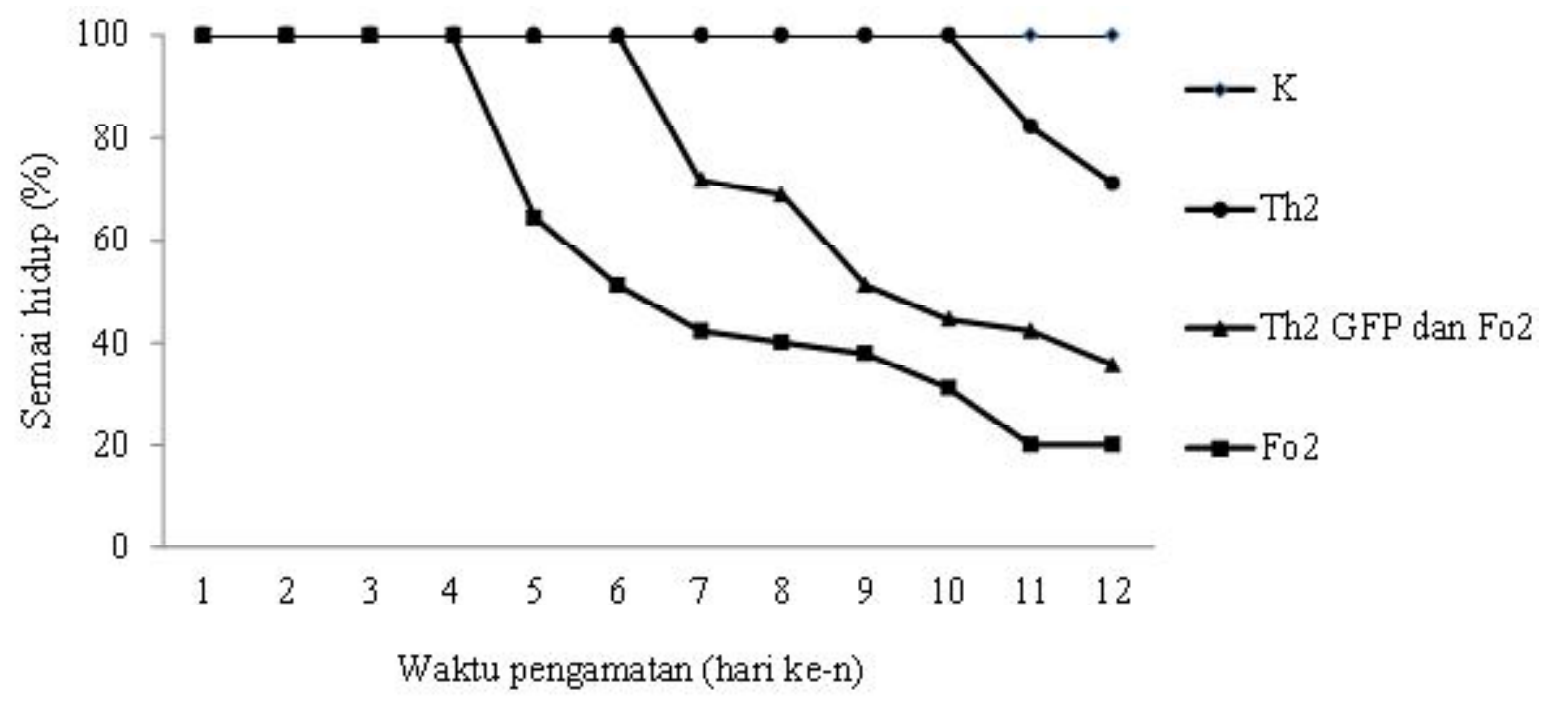

Gambar 9. Persentase hidup semai Acacia mangium setelah diinokulasi Trichoderma harzianum GFP dan Fusarium oxysporum. (K) Kontrol, (Th2) Inokulasi T. harzianum GFP 2 hari sebelum inokulasi F. oxysporum, (Th2 GFP dan Fo2) Inokulasi T. harzianum GFP dan F. oxysporum secara bersamaan, (Fo2) Inokulasi F. oxysporum 2 hari sebelum inokulasi T. harzianum GFP 
GFP yang menunjukkan rata-rata persentase hidup semai terendah $(64,44 \%)$. Hasil tersebut membuktikan bahwa keberadaan $T$. harzianum GFP sangat efektif dan berpengaruh nyata terhadap persentase hidup semai $A$. mangium bila diaplikasikan terlebih dahulu ke tanah di sekitar perakaran semai A. mangium. Mousseaux et al. (1998) melaporkan bahwa aplikasi T. harzianum terlebih dahulu lalu dilanjutkan dengan inokulasi campuran $T$. harzianum dan $F$. oxysporum pada semai Douglas-fir (Pseudotsuga menziesii var. glauca [Beissn.] Franco) terbukti efektif mengurangi tingkat kematian semai hingga 50\%.

Kesimpulan secara keseluruhan menunjukkan bahwa $F$. oxysporum secara in vitro melakukan penetrasi melalui stomata pada permukaan pangkal batang semai $A$. mangium, masuk hingga ke jaringan pembuluh floem dan xylem secara interseluler melalui ruang antar sel. Terjadi reaksi hipersensitif dan akumulasi lignin akibat infeksi $F$. oxysporum. Secara in vitro, kemampuan antagonistik T. harzianum GFP terlihat yaitu melalui penempelan pada hifa $F$. oxysporum kemudian menguasai koloni F.oxysporum dengan cara tumbuh memenuhi koloni $F$. oxysporum (12 hari inkubasi). Secara in planta, rata-rata persentase hidup semai A. mangium tertinggi ditunjukkan pada perlakuan inokulasi T. harzianum GFP 2 hari sebelum inokulasi $F$. oxysporum $(82,22 \%)$ dan terendah pada perlakuan inokulasi $F$. oxysporum 2 hari sebelum inokulasi $T$. harzianum GFP $(64,44 \%)$.

\section{SIMPULAN}

Mekanisme penghambatan terhadap Fusarium oxysporum oleh Trichoderma harzianum pada semai Acacia mangium adalah mekanisme parasitisme. Hal ini terlihat dengan adanya penempelan pada umur 7 hari masa inkubasi hingga pertumbuhan hifa T. harzianum yang tumbuh dan menutupi hifa $F$. oxysporum umur 12 hari masa inkubasi (secara in vitro). Secara in planta, daya parasitisme $T$. harzianum terhadap $F$. oxysporum terlihat melalui rata-rata persen hidup semai A. mangium. Rata-rata persentase hidup semai A. mangium tertinggi ditunjukkan pada perlakuan aplikasi T. harzianum 2 hari sebelum inokulasi F. oxysporum sebesar $82,22 \%$, dan terendah pada perlakuan inokulasi $F$. oxysporum 2 hari sebelum aplikasi $T$. harzianum sebesar $64,44 \%$.

\section{SANWACANA}

Ucapan terima kasih disampaikan kepada Tanoto Foundation atas dana yang diberikan, sehingga penelitian ini dapat terlaksana.

\section{DAFTAR PUSTAKA}

Achmad SH, Harran S, Sa'id EG, Satiawihardja B, \& Kardin K. 1997. Biochemical defense of Pinus merkusii seedlings against damping-off pathogens. Proceedings of the $\sigma^{\text {th }}$ International Workshop of BIO-REFOR. Brisbane. Australia. December 2-5, 1997.

Agrios GN. 2005. Plant Pathology. Elsivier Academic Press USA.

Goltapeh EM \& Danesh YR. 2006. Pathogenic interactions between Trichoderma species and Agaricus bisporus. J. Agric. Technol. 2(1): 29-37.

Grondona I, Hermosa R, Tejada M, Gomis MD, Mateos PF, Bridge PD, Monte E, \& Garcia-acha I. 1997. Physiological and biochemical characterization of Trichoderma harzianum, a biological control agent against soilborne fungal plant pathogens. Appl. Environ. Microbiol. 63: 3189-3198.

Hardiyanto EB \& Arisman H. 2004. Pembangunan Hutan Tanaman Acacia mangium: Pengalaman di Sumatera Selatan Musi Hutan Persada. PT. Musi Hutan Persada. Palembang. Sumatera Selatan.

Harjono \& Widyastuti SM. 2001. Permurnian dan karakteristik enzim endokitinase dari agen pengendali hayati Trichoderma reesei. J. Perlind. Tan. Indones. 7(1): 114-120.

Küçük Ç \& Kivanç M. 2003. Isolation of Trichoderma spp. and determination of their antifungal, biochemical and physiological features. Turk. J. Biol. 27: 247-253.

Machón P, Pajares JA, Diez JJ, \& Alves-Santos FM. 2009. Influence of the ectomycorrhizal fungus Laccaria laccata on pre-emergence, postemergence and late damping-off by Fusarium oxysporum and $F$. verticillioides on stone pine seedlings. Symbiosis 49(2): 101-109. 
Mousseaux MR, Dumroese RK, James RL, Wenny DL, \& Knudsen GR. 1998. Effcacy of Trichoderma harzianum as a biological control of Fusarium oxysporum in container-grown Douglas-fir seedlings. New Forest. 15(1): 11-21.

Nakas JP \& Hagedorn C. 1990. Biotechnology of Plant-Microbe Interactions. McGraw-Hill. New York.

Salerno ML, Gianinazzi S, \& Gianinazzi-Pearson V. 2000. Effects on growth and comparison of root tissue colonization patterns of Eucalyptus viminalis by pathogenic and nonpathogenic strains of Fusarium oxysporum. New Phytol. 146(2):317-324.

Widyastuti SM. 2007. Peran Trichoderma dalam Revitalisasi Kehutanan di Indonesia. Gadjah Mada University Press. Yogyakarta.
Widyastuti SM, Harjono, Sumardi, \& Yuniarti D. 2003. Biological control of Sclerotium rolfsii damping-off with three isolates of Trichoderma spp. Online J. Biol. Sci. 3(1): 95-102.

Widyastuti SM, Sumardi, \& Sumantoro P. 2001. Efektivitas Trichoderma spp. sebagai pengendali hayati terhadap tiga patogen tular tanah pada beberapa jenis tanaman kehutanan. J. Perlind. Tan. Indones. 7(2): 98-107.

Witkowska D \& Maj A. 2002. Production of lytic enzymes by Trichoderma spp. and their effect on the growth of phytopathogenic fungi. Folia Microbiol. 47(3): 279-282. 